\title{
Epidemiology of childhood trauma at the Lady Ridgeway Children's Hospital, Colombo
}

\author{
Shamin P Lamabadusuriya ${ }^{1}$, Dinuka Lankeshwara ${ }^{1}$, D B N Kuruwitaarachchi ${ }^{1}$ \\ Sri Lanka Journal of Child Health, 2002; 31: 46-54
}

(Key words: Epidemiology, trauma, children)

\begin{abstract}
Objective To study the pattern of injuries and sociodemographic characteristics of children seeking treatment at the Lady Ridgeway Hospital, Colombo (LRH) following trauma.
\end{abstract}

Design A descriptive cross-sectional study

Setting Accident service in LRH

Patients All children less than 13 years of age seeking treatment at the LRH accident service on two randomly selected week days and two randomly selected weekend days.

Method Data was collected using an intervieweradministered questionnaire and was processed manually.

Results 171 children with trauma were tabulated according to type of injury, sex, age, presence of past history of trauma, mother's level of education, site of injury, cause, location, mother's employment status, family income etc.

\section{Introduction}

With the reduction in incidence of infectious diseases, traumatic injuries are playing an important role in childhood morbidity and mortality.

The annual health bulletin, 1999 ranks accidents as the second leading cause of death in the 5-14 year age group and the third leading cause of death in the 1-4 year age group in $1996^{1}$. Traumatic injuries include accidental injuries and injuries due to intentional violence.

Accidents occur more frequently in certain age groups, at certain times of the day and week, and in certain localities. Majority of childhood accidents are preventable ${ }^{2}$. These include home accidents, road traffic accidents, sports accidents and injuries caused by animals.

\footnotetext{
${ }^{1}$ Medical Student, University of Colombo.
}

Childhood is an important period for intentional violence. The child can get injured following violence by caretakers, friends and siblings.

\section{Setting}

The accident service of the Lady Ridgeway Hospital for Children, Colombo (LRH) is an ideal setting for the study. This is a tertiary care institution receiving a large number of trauma victims daily. Thus, a large number of patients could be covered in a short period of time making the research viable with available resources. Furthermore, being easily accessible to Colombo and its suburbs, a wide spectrum of injuries could be seen making the study more accurate.

\section{Objective}

To study the pattern of injuries and socio demographic characteristics of children seeking treatment at LRH following trauma.

\section{Study design}

This was a descriptive cross-sectional study. This study design was chosen as it involves fewer resources (manpower, money, material and time) and was suitable to meet the objective.

\section{Method}

The study population comprised all children less than 13 years of age seeking treatment at the accident service of LRH irrespective of whether they were having actual injuries or not. As a sub group, all admissions to medical wards of LRH with poisoning was taken.

Children meeting the above selection criteria, presenting to LRH on 2 randomly selected week days and 2 randomly selected weekend days, was taken as the sample population. The 2 week days were 19 th and 20th July 2001 whilst the 2 weekend days were 15th and 29th July 2001. The sampling method was convenient sampling. 
The study instrument was an interviewer administered questionnaire consisting of five main parts:

1. General information (socio-demographic characteristics).

2. Type of injury and its cause.

3. Time and location of injury.

4. Site of injury in body.

5. Type of tissue injury.

The interviewers were the 3 authors. They underwent training on how to administer the questionnaire beforehand. Data processing was done manually. Data analysis was done using two methods:

1. Simple descriptive methods using absolute numbers and percentages represented in table form.

2. Statistical tests to check significance of proportions of one sample in selected areas.

This study was informally granted ethical approval by the Department of Community Medicine, Faculty of Medicine, University of Colombo. Permission was granted by the director of LRH to conduct the study. Informed consent was obtained from all parents and guardians of the subjects before administration of the questionnaire.

\section{Definitions of selected variables}

- $\quad$ Age - age at last birthday.

- $\quad$ Family income - average monthly income of all family members, except married children, during the past year.

- Home accidents - accidents occurring at apartments, boarding houses, farm houses, residential homes, non institutional places of residence, drive ways to homes, garages, gardens, yards and swimming pools in private houses. Excludes abandoned or derelict houses, homes under construction but not occupied, institutional places of residence ${ }^{3}$.

- Road traffic accidents - any vehicular accident occurring on public highways ${ }^{3}$.
- Intentionally caused injuries - injuries caused with deliberate motivation of causing harm to one person by the same or another person excluding poisoning.

- Sports injuries - accidents occurring while engaging in physical exercise with a described functional element.

- Burns - damage to skin and underlying tissues from dry heat, flames, flashes, friction, chemicals, electricity, radiation and cold ${ }^{4}$.

- Scalds - damage to skin and underlying tissues from hot liquids or gases ${ }^{4}$.

- Abrasion - damage to exposed superficial layers of skin $^{4}$.

- Laceration - Splits in a tissue or organ located on its surface or within it $^{4}$.

- Contusions - visible extravasations of blood into tissues due to rupture of blood vessels following mechanical trauma ${ }^{4}$.

- Cuts - gaps in tissue characterized by concave margins, sharply pointed ends and regular walls where the length of the incision is greater than the depth ${ }^{4}$.

- Stabs - gaps in tissue characterized by concave margins, sharply pointed ends and regular walls where the depth of the incision is greater than the length ${ }^{4}$.

- Fracture - injuries of bone, cartilage or teeth diagnosed by clinical features and/or radiological findings ${ }^{4}$.

\section{Results and analysis}

The type of injury is shown in table 1 .

Table 1

Type of injury

\begin{tabular}{|l|c|}
\hline Type of injury & Number (\%) \\
\hline Home accidents & $95(56)$ \\
\hline Injuries caused by animals & $36(21)$ \\
\hline Road traffic accidents & $14(08)$ \\
\hline Intentional violence & $08(05)$ \\
\hline Sports injuries & $05(03)$ \\
\hline Other & $13(07)$ \\
\hline Total & $171(100)$ \\
\hline
\end{tabular}


$56 \%$ injuries were due to home accidents.

The sex distribution of children is shown in table 2 .

Table 2

Sex distribution of children

\begin{tabular}{|l|c|c|}
\hline \multicolumn{1}{|c|}{ Type of injury } & $\begin{array}{c}\text { No. of } \\
\text { males (\%) }\end{array}$ & $\begin{array}{c}\text { No. of } \\
\text { females (\%) }\end{array}$ \\
\hline Home accidents & $48(50)$ & $47(64)$ \\
\hline $\begin{array}{l}\text { Injuries caused by } \\
\text { animals }\end{array}$ & $24(25)$ & $12(16)$ \\
\hline $\begin{array}{l}\text { Road traffic } \\
\text { accidents }\end{array}$ & $06(6)$ & $08(10)$ \\
\hline Intentional violence & $06(6)$ & $02(3)$ \\
\hline Sports injuries & $05(5)$ & $00(0)$ \\
\hline Others & $08(8)$ & $05(7)$ \\
\hline Total & $97(100)$ & $74(100)$ \\
\hline
\end{tabular}

$57 \%$ were males and $43 \%$ were females.

$50 \%$ males and $64 \%$ females presented with home accidents. The female predominance was statistically significant $(\mathrm{p}<0.05)$.
$25 \%$ males and $16 \%$ females had injuries caused by animals. The male predominance was not statistically significant. $(\mathrm{p}>0.05)$

$6 \%$ males and $10 \%$ females were victims of road traffic accidents. The female predominance was not statistically significant. $(\mathrm{p}>0.05)$

$6 \%$ males and $3 \%$ females were subjects of intentional violence. The male predominance was not statistically significant. $(\mathrm{p}>0.05)$

$5 \%$ males and $0 \%$ females were involved in sports accidents. The male predominance was statistically significant. $(\mathrm{p}<0.05)$

The age distribution in victims of trauma is shown in table 3 .

Table 3

\section{Age distribution of the children}

$\begin{array}{ccccccc}\text { Age in years } & \begin{array}{c}\text { No. of home } \\ \text { accidents (\%) }\end{array} & \begin{array}{c}\text { No. of injuries } \\ \text { caused by } \\ \text { animals (\%) }\end{array} & \begin{array}{c}\text { No. of road } \\ \text { traffic } \\ \text { accidents (\%) }\end{array} & \begin{array}{c}\text { No. due to } \\ \text { intentional } \\ \text { violence (\%) }\end{array} & \begin{array}{c}\text { No. of sports } \\ \text { injuries (\%) }\end{array} & \begin{array}{c}\text { No. of other } \\ \text { injuries (\%) }\end{array} \\ -1 & 14(15) & 01(3) & 00(0) & 01(12) & 00(0) & 00(0) \\ -4 & 44(46) & 07(19) & 08(58) & 01(12) & 00(0) & 08(62) \\ -9 & 29(31) & 18(50) & 03(21) & 05(64) & 04(80) & 02(15) \\ -12 & 08(8) & 10(28) & 03(21) & 01(12) & 01(20) & 03(23) \\ \text { Total } & 95(100) & 36(100) & 14(100) & 08(100) & 05(100) & 13(100)\end{array}$

$46 \%$ home accidents occurred in the 1-4 year age group whilst $50 \%$ animal injuries occurred in the 5-9 year age group.

Distribution of children according to past history of trauma is shown in table 4 .

Table 4

Distribution of children according to past history of trauma

\begin{tabular}{|c|c|}
\hline Past history of trauma & Number (\%) \\
\hline Absent & $126(74)$ \\
\hline Present & $45(26)$ \\
\hline Total & $171(100)$ \\
\hline
\end{tabular}

Only $26 \%$ of trauma victims had a past history of trauma.

Distribution of children according to their mother's education level is shown in table 5 .

In the analysis of mother's level of education no regular relationship was observed in any type of trauma.

The sites of injury in children is shown in table 6 .

In home accidents, commonest sites of injury were the head $(46 \%)$, face $(21 \%)$, upper limb $(18 \%)$ and lower $\operatorname{limb}(7 \%)$.

In injuries caused by animals, the commonest sites were lower limbs (41\%), upper limbs (31\%) and face (22\%). 
Table 5

Mother's level of education in the various types of injury

\begin{tabular}{|c|c|c|c|c|c|c|}
\hline $\begin{array}{l}\text { Mother's level } \\
\text { of education }\end{array}$ & $\begin{array}{l}\text { No. of home } \\
\text { accidents (\%) }\end{array}$ & $\begin{array}{l}\text { No. of injuries } \\
\text { caused by } \\
\text { animals (\%) }\end{array}$ & $\begin{array}{l}\text { No. of road } \\
\text { traffic } \\
\text { accidents }\end{array}$ & $\begin{array}{l}\text { No. due to } \\
\text { intentional } \\
\text { violence (\%) }\end{array}$ & $\begin{array}{l}\text { No of sports } \\
\text { injuries (\%) }\end{array}$ & $\begin{array}{l}\text { No. of other } \\
\text { injuries (\%) }\end{array}$ \\
\hline $\begin{array}{l}\text { Not gone to } \\
\text { school }\end{array}$ & 03 (3) & $02(6)$ & $02(14)$ & $02(25)$ & $00(0)$ & $00(0)$ \\
\hline - year 5 & $06(6)$ & $01(3)$ & $02(14)$ & $01(12.5)$ & $00(0)$ & $02(15)$ \\
\hline - year 9 & $15(16)$ & $05(14)$ & $03(22)$ & $02(25)$ & $01(20)$ & $04(31)$ \\
\hline$-\mathrm{O} / \mathrm{L}$ & $21(22)$ & $08(22)$ & $02(14)$ & $01(12.5)$ & $01(20)$ & $00(0)$ \\
\hline - O/L passed & $27(29)$ & $12(33)$ & $02(14)$ & $01(12.5)$ & $02(40)$ & $01(8)$ \\
\hline$-\mathrm{A} / \mathrm{L}$ & $08(8)$ & $00(0)$ & $00(0)$ & $00(0)$ & $00(0)$ & $00(0)$ \\
\hline - A/L passed & $14(15)$ & $06(16)$ & $01(8)$ & $00(0)$ & $01(20)$ & $04(31)$ \\
\hline $\begin{array}{l}\text { - Highero } \\
\text { education }\end{array}$ & r00 (0) & $02(6)$ & $00(0)$ & $00(0)$ & $00(0)$ & $02(15)$ \\
\hline - Not available & $01(1)$ & $00(0)$ & $02(14)$ & $01(12.5)$ & $00(0)$ & $00(0)$ \\
\hline Total & $95(100)$ & $36(100)$ & $14(100)$ & $8(100)$ & $5(100)$ & $13(100)$ \\
\hline
\end{tabular}

Table 6

The site of injury in children

$\begin{array}{lcccccc}\text { Site } & \begin{array}{c}\text { No. of home } \\ \text { accidents (\%) }\end{array} & \begin{array}{c}\text { No. of injuries } \\ \text { caused by } \\ \text { animals (\%) }\end{array} & \begin{array}{c}\text { No. of road } \\ \text { traffic accidents }\end{array} & \begin{array}{c}\text { No. due to } \\ \text { intentional } \\ \text { violence (\%) }\end{array} & \begin{array}{c}\text { No of sports } \\ \text { injuries (\%) }\end{array} & \begin{array}{c}\text { No. of other } \\ \text { injuries (\%) }\end{array} \\ \text { Head } & 44(46) & 01(3) & 05(36) & 05(64) & 03(60) & 04(31) \\ \text { Face } & 20(21) & 08(22) & 01(7) & 01(12) & 01(20) & 04(31) \\ \text { Neck } & 00(0) & 00(0) & 00(0) & 00(0) & 00(0) & 00(0) \\ \text { Chest } & 01(1) & 00(0) & 01(7) & 00(0) & 00(0) & 00(0) \\ \text { Abdomen } & 03(4) & 00(0) & 00(0) & 00(0) & 00(0) & 00(0) \\ \text { Pelvis } & 00(0) & 01(3) & 00(0) & 00(0) & 00(0) & 00(0) \\ \text { Perineum } & 00(0) & 00(0) & 01(7) & 00(0) & 00(0) & 00(0) \\ \text { Upper limb } & 17(18) & 11(31) & 01(7) & 01(12) & 01(20) & 02(15) \\ \text { Lower limb } & 07(7) & 15(41) & 05(36) & 01(12) & 00(0) & 02(15) \\ \text { No injury } & 01(1) & 00(0) & 00(0) & 00(0) & 00(0) & 01(8) \\ \text { Not applicable } & 02(2) & 00(0) & 00(0) & 00(0) & 00(0) & 00(0) \\ \text { Total } & 95(100) & 36(100) & 14(100) & 8(100) & 5(100) & 13(100)\end{array}$


The causes of home accidents are shown in table 7.

Table 7

Causes of home accidents

\begin{tabular}{|l|c|}
\hline Cause of the accident & Number $(\%)$ \\
\hline Falls & $66(70)$ \\
\hline Falling objects & $06(06)$ \\
\hline Collisions & $05(05)$ \\
\hline Burns/ scalds & $03(03)$ \\
\hline Pricks & $02(02)$ \\
\hline Poisoning & $02(02)$ \\
\hline Cut & $01(01)$ \\
\hline Crushing & $01(01)$ \\
\hline Electricity & $00(00)$ \\
\hline Other & $09(10)$ \\
\hline Total & $95(100)$ \\
\hline
\end{tabular}

$70 \%$ home accident were caused by falls and $10 \%$ by 'other' injuries. 4 such injuries were due to deliberate insertion of seeds, buttons and small metal objects into natural orifices like nose and ear. One case needed ENT referral as the object was still inside the ear.

There were 3 cases of burns due to spilling of a tea cup, contact with an incense holder and a fire in the garden respectively.

Of the 2 cases of poisoning, one was due to paracetamol overdose and the other to ingestion of a piece of mosquito coil.

The cause of fall is shown in table 8 .

Table 8

\section{Cause of fall}

\begin{tabular}{|l|c|}
\hline Cause offall & Number (\%) \\
\hline $\begin{array}{l}\text { Falling from a height other } \\
\text { than a tree }\end{array}$ & $20(30)$ \\
\hline Slipping & $18(27)$ \\
\hline Tripping & $11(17)$ \\
\hline Falling from a tree & $06(09)$ \\
\hline Following collision & $05(08)$ \\
\hline Fits & $00(00)$ \\
\hline Fainting & $00(00)$ \\
\hline Other & $06(09)$ \\
\hline Total & $66(100)$ \\
\hline
\end{tabular}

$30 \%$ falls in children were due to falling from a height other than a tree.

The location of home accident is shown in table 9.
Table 9

Location of home accident

\begin{tabular}{|l|c|}
\hline Location & Number (\%) \\
\hline Inside house & $58(61)$ \\
\hline Garden & $32(34)$ \\
\hline Bathroom & $02(02)$ \\
\hline Kitchen & $02(02)$ \\
\hline Other & $01(01)$ \\
\hline Total & $95(100)$ \\
\hline
\end{tabular}

$61 \%$ of home accidents occurred in places inside the house other than the kitchen and bathroom. $34 \%$ occurred outdoors.

The type of tissue injury in home accident victims is shown in table 10 .

Table 10

Type of tissue injury in home accident victims

\begin{tabular}{|l|c|}
\hline Type of tissue injury & Number (\%) \\
\hline Laceration & $23(24)$ \\
\hline Contusion & $17(18)$ \\
\hline Abrasion & $10(11)$ \\
\hline Swelling & $09(10)$ \\
\hline Fracture & $08(08)$ \\
\hline Burn & $03(03)$ \\
\hline Cuts & $01(01)$ \\
\hline Other & $03(03)$ \\
\hline No visible injury & $21(22)$ \\
\hline Total & $95(100)$ \\
\hline
\end{tabular}

$24 \%$ of home accident victims had sustained lacerations

Employment status of mothers of home accident victims is shown in table 11 .

Table 11

Employment status of mothers of home accident victims

\begin{tabular}{|l|c|}
\hline $\begin{array}{c}\text { Mother's employment } \\
\text { status }\end{array}$ & Number (\%) \\
\hline Mother unemployed & $80(84)$ \\
\hline Mother employed & $15(16)$ \\
\hline Total & $95(100)$ \\
\hline
\end{tabular}

$84 \%$ mothers were unemployed.

The monthly family income of home accident victims is shown in table 12 . 
Table 12

Monthly family income of home accident victims

\begin{tabular}{|l|c|}
\hline $\begin{array}{l}\text { Monthly family income } \\
\text { in rupees }\end{array}$ & Number (\%) \\
\hline-2500 & $05(05)$ \\
\hline-5000 & $25(26)$ \\
\hline-7500 & $24(25)$ \\
\hline$-10,000$ & $18(19)$ \\
\hline$>10,000$ & $11(12)$ \\
\hline Not available & $12(13)$ \\
\hline Total & $95(100)$ \\
\hline
\end{tabular}

Monthly family income was less than Rs.2500 in only $5 \%$ accident victims.

The animal involved in traumatic injuries is shown table 13 .

Table 13

Animal involved in traumatic injuries

\begin{tabular}{|l|c|}
\hline \multicolumn{1}{|c|}{ Animal } & Number (\%) \\
\hline Dog & $29(80)$ \\
\hline Cat & $05(14)$ \\
\hline Rat & $01(03)$ \\
\hline Bull & $01(03)$ \\
\hline Total & $36(100)$ \\
\hline
\end{tabular}

$80 \%$ of victims had been injured by dogs and $14 \%$ by cats.

The manner of injury in victims of animal injuries is shown in table 14.

Table 14

The manner of injury in victims of animal injuries

\begin{tabular}{|l|c|}
\hline \multicolumn{1}{|c|}{ Manner of injury } & Number (\%) \\
\hline Bites & $33(92)$ \\
\hline Scratch & 02 \\
\hline Other & 01 \\
\hline Total 36 100 & 36 \\
\hline
\end{tabular}

$92 \%$ of injuries had been caused by bites.

Presence or absence of provocation in animal injuries is shown in table 15 .

Table 15

Presence or absence of provocation in animal injuries

\begin{tabular}{|l|c|}
\hline $\begin{array}{c}\text { Presence or absence } \\
\text { of provocation }\end{array}$ & Number (\%) \\
\hline Unprovoked & $21(58)$ \\
\hline Provoked & $15(42)$ \\
\hline Total & $36(100)$ \\
\hline
\end{tabular}

$58 \%$ victims had sustained the in-jury without provocation.
The location of injury is shown in table 16 .

Table 16

The location of injury

\begin{tabular}{|l|c|}
\hline Location & Number $(\%)$ \\
\hline Home garden & $14(39)$ \\
\hline Inside house & $11(30)$ \\
\hline Road & $07(19)$ \\
\hline School garden & $02(06)$ \\
\hline Other & $02(06)$ \\
\hline Total & $36(100)$ \\
\hline
\end{tabular}

$39 \%$ had sustained injuries in their home garden and $30 \%$ inside their houses.

Vehicles involved in road traffic accidents are shown in table 17.

Table 17

Vehicles involved in road traffic accidents

\begin{tabular}{|l|c|}
\hline $\begin{array}{c}\text { Vehicle involved in } \\
\text { road traffic accident }\end{array}$ & Number (\%) \\
\hline Bicycle & $06(43)$ \\
\hline Motor cycle & $05(36)$ \\
\hline Three wheeler & $01(07)$ \\
\hline Others & $02(14)$ \\
\hline Total & $14(100)$ \\
\hline
\end{tabular}

In $43 \%$ of cases, it was the bicycle and in $36 \%$ the motor cycle.

The situation of the victim at the time of the road traffic accident is shown in table 18 .

Table 18

Situation of victim at time of road traffic accident

\begin{tabular}{|l|c|}
\hline \multicolumn{1}{|c|}{ Situation of the victim } & Number (\%) \\
\hline Pedestrian & $07(50)$ \\
\hline Pillion rider (bicycle) & $04(29)$ \\
\hline $\begin{array}{l}\text { Pillion rider (motor } \\
\text { cycle) }\end{array}$ & $02(14)$ \\
\hline Other & $01(07)$ \\
\hline Total & $14(100)$ \\
\hline
\end{tabular}

In $50 \%$ of instances, the child had been a pedestrian.

A peculiar pattern of injury was identified in the 4 children who were pillion riders of bicycles. The foot had been caught between the spokes of the front wheel and had got injured.

Distribution of victims of intentional violence according to person causing harm is shown in table 19. 
Table 19

Person causing harm in intentional violence

\begin{tabular}{|l|c|}
\hline \multicolumn{1}{|c|}{ Person causing harm } & Number (\%) \\
\hline Friend & $05(54)$ \\
\hline Sibling & $01(12)$ \\
\hline Self & $01(12)$ \\
\hline Other & $01(12)$ \\
\hline Total & $08(100)$ \\
\hline
\end{tabular}

$64 \%$ of the injuries caused by intentional violence had been caused by a friend.

\section{Discussion}

Several research studies have been carried out regarding accidental trauma and home accidents in Sri Lanka ${ }^{5,6,7}$. In a study carried out at the accident service of the National Hospital of Sri Lanka in 1982, $17 \%$ of injuries followed intentional violence ${ }^{5}$. However, in our study only $5 \%$ of injuries followed intentional violence. This finding may be misleading as injuries caused by intentional violence in children do not always present to hospital.

Home accidents account for 56\% injuries in our study. This is considerably higher than the $20 \%$ in adults ${ }^{5}$. Road traffic accidents account for $38 \%$ injuries in adults ${ }^{5}$ compared with $8 \%$ children in our study. Injuries caused by animals accounted for $21 \%$ in our study but only $0.2 \%$ in adults ${ }^{5}$. Sports injuries were found in $3 \%$ in our study compared to $7 \%$ in adults ${ }^{5}$. The lower incidence of sports injuries in children may be due to several reasons:

- Children not getting involved in sports likely to cause significant injuries.

- Children not complaining about sports injuries to parents.

- $\quad$ Parents not being worried about sports injuries in children and hence not taking the child to hospital.

- Child receiving treatment at a primary health care centre rather than LRH.

There was an overall male predominance in children with traumatic injuries. $74 \%$ did not have a past history of trauma.

\section{Home accidents}

Home accidents were significantly commoner in girls $(p<0.05)$. This agrees with the finding that $57 \%$ of home accidents occurred in adult females ${ }^{5}$. However this finding differs from that of a previous study in children where home accidents were found to be commoner among boys ${ }^{7}$.
$46 \%$ home accidents occurred in the 1-4 year age group. This finding is similar to that of a previous hospital-based study $^{7}$. This can be due to several reasons:

- They spend more time at home than older children.

- Their behaviour makes them more susceptible to home accidents.

Falls $(70 \%)$ were the commonest cause of home accidents. This agrees with the findings of 2 previous hospital-based studies ${ }^{5,7}$. However, in a study involving patients in general practice, cuts due to sharp objects was the commonest cause6. Although in adults, falling at ground level account for the majority $^{5}$, in children it was falling from a height other than a tree. Slipping and tripping, which is the commonest cause of falls in adults ${ }^{5}$, was important in this study too.

In adults bathroom, toilet and kitchen were the commonest location of home accidents ${ }^{5}$. However, in our study these were not the major locations for home accidents.

The very high percentage of children having unemployed mothers among the home accident victims (84\%) suggests that employment of the mother per se does not make the child more susceptible to home accidents.

There was no regular relationship between mothers' level of education and the incidence of home accidents.

The relatively lower incidence of home accident victims among low-income families in our study can be due to different factors.

- Parents pay less attention to minor injuries in their children and hence do not bring them to hospital for treatment.

- They may seek treatment from primary health care centres rather than bringing the child to a tertiary care hospital.

\section{Injuries caused by animals}

As boys tend to provoke animals more than girls, they should be more liable to this type of injury but this is not reflected in this study. The $50 \%$ incidence in the 4-9 year age group can be attributed to the changes in behaviour during this period. The $41 \%$ injuries in lower limbs is expected but the $22 \%$ facial injuries are important because

- Risk of rabies is higher in facial injuries.

- This can cause permanent disfigurement of face. 
$58 \%$ injuries by animals were unprovoked. Thus provocation is not a major factor in animal injuries.

$69 \%$ of the children had sustained injuries in their home garden or inside their own house. Therefore, the pet is often causing the injury.

\section{Road traffic accidents}

There was no statistically significant difference between the proportion of boys and girls sustaining road traffic accidents. Injuries caused by the foot being caught in the spokes of the front wheel was an important finding in pillion riders of bicycles.

\section{Intentional violence}

$64 \%$ cases of intentional violence were caused by a friend. Violence by caretaker was not a feature in our study.

\section{Other injuries}

Insertion of a foreign object into a natural orifice is an important cause of injuries in children.

\section{Preventive measures}

Preventive measures should target home accidents and injuries caused by animals.

1. Children between 1-4 years should be closely supervised by an adult when climbing heights from where dangerous falls can occur.

2. Small objects, which the children are likely to insert into natural orifices, should be kept out of reach of children.

3. Parents should be advised to seek treatment for minor injuries from primary health care centres.

4. All domestic dogs should be immunized at the correct time as children are often injured by them.

5. Children should be discouraged from provoking stray dogs to prevent injuries from this dangerous source.

6. Parents should be more careful when carrying the child on the bicycle bars.

\section{Limitations of the study}

- We had to use the convenient sampling method because of limitation of resources. This is not a very scientific method to carry out sampling.
- The study setting was a tertiary care hospital which receives transfers with more serious injuries as well as direct admissions. This can affect the result by increasing the severity of the spectrum of injuries. Thus, this population may not properly represent the children in Sri Lanka.

- In this study, the time spent by the mother with the child was not measured as a risk factor for childhood trauma.

- We did not assess the relationship between the mother's personality and the Childs proneness to accidents.

- The relationship between the child's personality and the traumatic injuries was not assessed.

\section{Acknowledgements}

We thank our group tutor Dr. N. Janakan for his timely guidance, Professor Lalani Rajapakse for making the necessary amendments, the staff of the Department of Community Medicine, Faculty of Medicine, University of Colombo, the staff at the accident service, LRH, all the participants of the study and their parents/guardians.

\section{References}

1. Annual Health Bulletin 1999, Ministry of Health Services Sri Lanka.

2. Park K. Park's textbook of preventive and social medicine. 14th ed. Jabalpur; Banarsidas Bhanot, 1995.

3. World Health Organization. ICD-10 International Statistical Classification of Diseases and Related Health Problems. WHO 1994.

4. Babapulle C J. Medicolegal Aspects of Injuries Peradeniya: 2000.

5. Ediriweera S A. Accidental Trauma. Ceylon Medical Journal 1984; 29: 3-22.

6. Aloysius D J. Home Accidents in Sri Lanka. Ceylon Medical Journal 1984; 191: 29-33.

7. Athauda G A T K, Rajapaksa L C. Some factors influencing home accidents. Journal of College of Community Physicians of Sri Lanka 1996; 1: $30-5$. 